\title{
Correction to: Phenytoin inhibits necroptosis
}

Anne von Mässenhausen ${ }^{1}$, Wulf Tonnus $\mathbb{D}^{1}$, Nina Himmerkus², Simon Parmentier', Danish Saleh ${ }^{3}$, Diego Rodriguez ${ }^{4}$, Jiraporn Ousingsawat ${ }^{5}$, Rosalind L. Ang ${ }^{6}$, Joel M. Weinberg ${ }^{7}$, Ana B. Sanz ${ }^{8}$, Alberto Ortiz $\mathbb{0}^{8}$, Adrian Zierleyn ${ }^{1}$, Jan Ulrich Becker ${ }^{9}$, Blandine Baratte ${ }^{10}$, Nathalie Desban ${ }^{10}$, Stéphane Bach ${ }^{10}$, Ina Maria Schiess ${ }^{5}$, Shoko Nogusa ${ }^{11}$, Siddharth Balachandran ${ }^{11}$, Hans Joachim Anders ${ }^{12}$, Adrian T. Ting ${ }^{6}$, Markus Bleich², Alexei Degterev ${ }^{3}$, Karl Kunzelmann ${ }^{5}$, Stefan R. Bornstein ${ }^{1}$, Douglas R. Green ${ }^{4}$, Christian Hugo ${ }^{1}$ and Andreas Linkermann (1) ${ }^{1}$

Correction to: Cell Death and Disease (2018) 9:359. https://doi.org/10.1038/s41419-018-0394-3; Article published online: 02 Mar 2018.

The name of the one of the authors was misspelt. The author's surname is Rodriguez, not Rodriquez as originally published. This has been corrected in both the PDF and HTML versions of the Article.

Correspondence: Andreas Linkermann (andreas.linkermann@ukdd.de)

'Division of Nephrology, Medical Clinic 3, University Hospital Carl Gustav Carus, Technical University Dresden, Dresden, Germany

${ }^{2}$ Department of Physiology, University of Kiel, Kiel, Germany

${ }^{3}$ Sackler School of Graduate Biomedical Sciences, Tufts University School of Medicine, Boston, MA, USA

${ }^{4}$ Department of Immunology, St. Jude Medical Research Hospital, Memphis,

TN, USA

${ }^{5}$ Institute for Physiology, University of Regensburg, Regensburg, Germany

${ }^{6}$ Immunology Institute, Icahn School of Medicine at Mount Sinai, New York, NY 10029, USA

${ }^{7}$ Department of Internal Medicine, University of Michigan, Ann Arbor, MI, United States

${ }^{8}$ Nephrology, IIS-Fundacion Jimenez Diaz UAM, FRIAT and REDINREN, Madrid, Spain

${ }^{9}$ Institute of Pathology, University of Cologne, Cologne, Germany

${ }^{10}$ Protein Phosphorylation and Human Disease Laboratory, Station Biologique de Roscoff UPMC Univ Paris 06 CNRS USR3151, CS 90074, Sorbonne

Universités, 29688 Roscoff Cedex, France

${ }^{11}$ Blood Cell Development and Function Program, Fox Chase Cancer Center,

Philadelphia, PA, USA

${ }^{12}$ Medizinische Klinik und Poliklinik IV, Klinikum der LMU München, Munich,

Germany

(c) The Author(s) 2018

(c) (i) Open Access This article is licensed under a Creative Commons Attribution 4.0 International License, which permits use, sharing, adaptation, distribution and reproduction cc) in any medium or format, as long as you give appropriate credit to the original author(s) and the source, provide a link to the Creative Commons license, and indicate if changes were made. The images or other third party material in this article are included in the article's Creative Commons license, unless indicated otherwise in a credit line to the material. If material is not included in the article's Creative Commons license and your intended use is not permitted by statutory regulation or exceeds the permitted use, you will need to obtain permission directly from the copyright holder. To view a copy of this license, visit http://creativecommons.org/licenses/by/4.0/. 